\title{
Effect of Delta-Tocotrienol on Melanin Content and Enzymes for Melanin Synthesis in Mouse Melanoma Cells
}

\author{
Akihiro Michinara, ${ }^{*}$ Saki Ogawa, Yohei Kamizaki, and Kenji Akasaki \\ Faculty of Pharmacy and Pharmaceutical Sciences, Fukuyama University; Fukuyama, Hiroshima 729-0292, Japan.
}

Received April 10, 2010; accepted June 21, 2010; published online June 28, 2010

\begin{abstract}
In the present study, we investigated the dose-dependent effect of $\delta$-tocotrienol long term $(48,72 \mathrm{~h})$ on the melanin content of cells treated with $\delta$-tocotrienol, and whether cells treated with $\delta$-tocotrienol for long a time show cytotoxicity. We also examined whether other enzymes responsible for melanin biosynthesis, tyrosinaserelated protein-1 (TRP-1) and -2 (TRP-2), are involved in the decrease in melanin levels. Protein levels in cells treated with 25 or $50 \mu_{\mathrm{M}} \delta$-tocotrienol for $48 \mathrm{~h}$ or $72 \mathrm{~h}$ were similar to those in control cells. Melanin content decreased by $44\left(25 \mu_{\mathrm{M}} \delta\right.$-tocotrienol) to $50 \%\left(50 \mu_{\mathrm{M}}\right)$ at $48 \mathrm{~h}$, and by 14 to $21 \%$ at $72 \mathrm{~h}$, compared to control levels. Tyrosinase activity, amounts of tyrosinase and TRP-1 decreased dependent on dose : by 50 ( $25 \mu \mathrm{M} \delta$-tocotrienol) to $75 \%(50 \mu \mathrm{M}), 20$ to $45 \%$ and 42 to $82 \%$ at $48 \mathrm{~h}$, and by 25 to $50 \%, 75$ to $80 \%$ and 78 to $77 \%$ at $72 \mathrm{~h}$, respectively. Although the amount of TRP-2 increased by $20 \%$ on treatment with $25 \mu \mathrm{M} \delta$-tocotrienol for $48 \mathrm{~h}$, it decreased by $52 \%$ on treatment with $50 \mu \mathrm{M} \delta$-tocotrienol for $48 \mathrm{~h}$. The amount of TRP-2 dose-dependently decreased by $55 \%$ and $75 \%$ on $72 \mathrm{~h}$ by treatment with 25 and $50 \mu_{\mathrm{M}} \delta$-tocotrienol, respectively. From these findings, $\delta$-tocotrienol at up to $50 \mu \mathrm{M}$ dose-dependently caused a reduction in melanin content by the decrease of TRP-1 and TRP-2 as well as tyrosinase, and no cytotoxicity.
\end{abstract}

Key words tocotrienol; melanin; tyrosinase related protein-1; tyrosinase related protein-2; tyrosinase

In nature, eight substances have been found to have vita$\min \mathrm{E}$ activity: $\alpha-, \beta-, \gamma-$, and $\delta$-tocopherol; and $\alpha-, \beta-, \gamma-$, and $\delta$-tocotorienol. ${ }^{1}$ Tocotrienols possess powerful antithrombotic, neuroprotective, anti-cancer, and cholesterollowering properties that are often not exhibited by tocopherols. $^{2-12)}$

Melanin is synthesized by tyrosinase and other enzymes in the tyrosinase family, such as tyrosinase-related protein (TRP)-1 and TRP-2, in melanosomes. We previously reported that the decrease $(35 \%)$ in the melanin content of mouse melanoma B16 cells treated with $50 \mu \mathrm{M} \delta$-tocotrienol for $24 \mathrm{~h}$ was the result of a decrease in the level of tyrosinase. ${ }^{13)} \delta$-Tocotrienol might also be useful as a therapeutic or preventive drug for hyperpigmentation and as a component of whitening and/or lightening cosmetics not causing severe side effect (reduction of cholesterol content and release of lysosomes/melanosomes), although $50 \mu \mathrm{M} \delta$ tocotrienol for $24 \mathrm{~h}$ caused a decrease in the level of mevalonate pyrophosphate decarboxylases, an enzyme involved in cholesterol biosynthesis. ${ }^{14)}$ Kamei et al. reported that $\delta$-tocopherol has cytotoxicity, although it shows antimelanogenic activity at a low concentration long term $(72 \mathrm{~h}) .{ }^{15)}$ Although in number and position of methyl groups on the chromanol ring, of $\delta$-tocotrienol is similar to $\delta$-tocopherol, $\delta$-tocotrienol possesses a farnesyl instead of a saturated phytyl side chain. Therefore, the antimelanogenic activity of $\delta$-tocotrienol and $\delta$-tocopherol seems to relate to the number and position of the methyl groups on the chromanol ring. Treatment with $\delta$-tocotrienol long term may also show cytotoxicity.

Thus, we investigated whether treatment with $\delta$-tocotrienol long term causes cytotoxicity, and also the dose-dependent effect of $\delta$-tocotrienol on melanin levels in cells. Furthermore, we examined whether other enzymes producing melanin, tyrosinase related protein-1 (TRP-1) and -2 (TRP2 ), are involved in the decrease in melanin content.

\section{MATERIALS AND METHODS}

Materials The $\delta$-tocotrienol (98.7\%) was obtained from Eisai Food Chemical (Tokyo, Japan). The cholesterol E-test Wako kits were from Wako (Osaka, Japan), Dulbecco's modified Eagle's medium (D-MEM) from Gibco (Tokyo, Japan), B16 cells from RIKEN (Ibaraki, Japan), rabbit anti-glyceraldehyde-3-phosphate dehydrogenase (GAPDH) immunoglobulin $\mathrm{G}(\mathrm{IgG})$, rabbit anti-TRP-2 IgG, goat anti-tyrosinase IgG, goat anti-TRP-1 IgG, and goat anti-lactate dehydrogenase (LDH: C-17) IgG from Santa Crutz Biotechnology, Inc. (Santa Crutz, CA, U.S.A.), rabbit anti-goat IgG conjugated to horseradish peroxidase from Invitrogen Corp. (San Clemente, CA, U.S.A.), and goat anti-rabbit IgG conjugated to horseradish peroxidase from Invitrogen Corp. (Carlsbad, CA, U.S.A.). All other chemicals were of reagent grade, and purchased from commercial sources.

Melanoma Cell Line B16 cells were diluted to $1.5 \times 10^{6}$ per $35-\mathrm{mm}$ tissue culture dish with D-MEM containing $10 \%$ fetal bovine serum (FBS), and then incubated in humidified air containing $5 \% \mathrm{CO}_{2}$ at $37^{\circ} \mathrm{C}$ for $24 \mathrm{~h}$. In some experiments, the cells were shifted to $1 \mathrm{ml}$ of D-MEM containing $10 \%$ FBS in the presence of 25 or $50 \mu \mathrm{M} \delta$-tocotrienol (dissolved in $1 \mu \mathrm{l}$ dimethyl sulfoxide (DMSO)) for 48 or $72 \mathrm{~h}$. One milliliter of D-MEM in the absence or presence of $\delta$-tocotrienol was exchanged at intervals of $1 \mathrm{~d}$.

Preparation of Samples B16 cells incubated on 35-mm dishes were washed several times in cold D-MEM. On the day of the experiment, the medium was aspirated from the culture dishes, and the cells were washed twice with $1 \mathrm{ml}$ of ice-cold phosphate buffered saline (PBS). Next, $600 \mu \mathrm{l}$ of homogenate buffer containing $1 \%$ triton X-100, $0.5 \mathrm{~mm}$ phenylmethylsulfonyl fluoride (PMSF), $10 \mathrm{~mm}$ 2-mercaptoethanol, $1 \mathrm{~mm}$ ethylenediaminetetraacetic acid (EDTA), and protease inhibitors $(1 \mu \mathrm{M}$ leupeptin, $1 \mu \mathrm{M}$ pepstatin A, $1 \mu \mathrm{M}$ chymostatin, and $1 \mu \mathrm{m}$ antipain) was added to the cells, which were then scraped off using a rubber policeman. The solution of 
B16 cells was homogenized with 5 strokes in a Teflon homogenizer. After centrifugation for $5 \mathrm{~min}$ at $10000 \times \boldsymbol{g}$, the post-nuclear supernatant (PNS) was used to assay tyrosinase activity and for immunoblotting.

Protein Assay Protein levels were measured by the method of Lowry et al. using bovine serum albumin (BSA) as the standard. ${ }^{16}$

Melanin Content Two hundred microliters in $600 \mu \mathrm{l}$ of PNS was used to measure melanin content. After centrifugation for $5 \mathrm{~min}$ at $10000 \times \mathbf{g}$, the precipitate of cells dissolved in $300 \mu \mathrm{l}$ of alkaline solution $(0.2 \mathrm{~N} \mathrm{NaOH})$ and incubated at $80^{\circ} \mathrm{C}$ for $1 \mathrm{~h}$ was used to measure melanin level. The amount of melanin was measured with a spectrophotometer at 420 nm. $^{17)}$

Tyrosinase Activity Twenty microliters of a $0.3 \%$ dopa solution was added to $10 \mu \mathrm{l}$ of supernatant (PNS) and $70 \mu \mathrm{l}$ of PBS, and incubated at $37^{\circ} \mathrm{C}$ for $90 \mathrm{~min}$. Tyrosinase activity was measured with a spectrophotometer at $475 \mathrm{~nm} .{ }^{18)}$

Sodium Dodecyl Sulfate-Polyacrylamide Gel Electrophoresis (SDS-PAGE) and Immunoblotting SDSPAGE was performed on $10 \%$ slab gels according to the method of Laemmli. ${ }^{19)}$ Proteins on the SDS-slab gel were

A
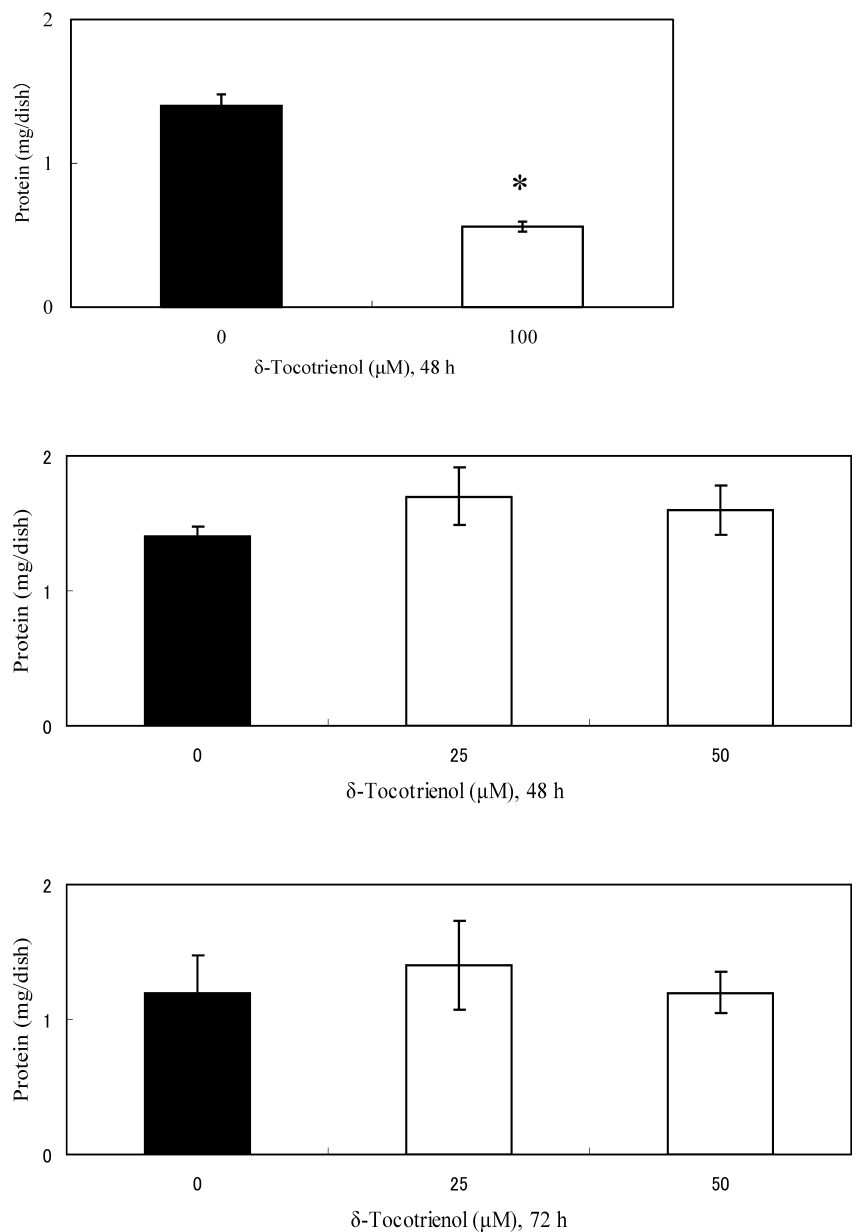

Fig. 1. Amounts of Protein and LDH in Cells Treated with $\delta$-Tocotrienol

(A) Protein levels in PNS were measured as described in Materials and Methods. (B) PNS (15 $\mu 1)$ was subjected to immunoblotting using anti-LDH and anti-GAPDH antiserum. (C) The signals in B were measured using an Intelligent Quantifier. GAPDH was used as an internal control. Data are the means for three identical experiments. Significant differences: $* p<0.0001$. transferred to a nylon membrane (NEN) by electrophoresis, using a modified version of the procedure of Towbin et al. ${ }^{20)}$ Positive bands were visualized using ECL Western blotting detection kits (Amersham Pharmacia, Amersham, U.K.) that contained a sensitive chemiluminescent substrate for horseradish peroxidase.

Statistics The statistical difference between results obtained at 0 and $25 \mu \mathrm{M}$, or 0 and $50 \mu \mathrm{M}$ at the same time points was carried out using Student's $t$-test. The statistical analysis for time $(48,72 \mathrm{~h})$ or concentration $(0,25,50 \mu \mathrm{M})$ was carried out using an analysis of vaiance. Data are presented as the mean \pm S.D.

\section{RESULTS}

The Effect of $\boldsymbol{\delta}$-Tocotrienol on Protein and LDH Levels in Cells We estimated the rate of survival of $\delta$-tocotrienoltreated and control cells by measuring amounts of protein. As shown in Fig. 1A, the amount of protein in cells treated with $100 \mu \mathrm{M} \delta$-tocotrienol for $48 \mathrm{~h}$ significantly decreased by $60 \%$, as compared with control values. Therefore, it was suggested that cells treated with $100 \mu \mathrm{M} \delta$-tocotrienol for $48 \mathrm{~h}$

B

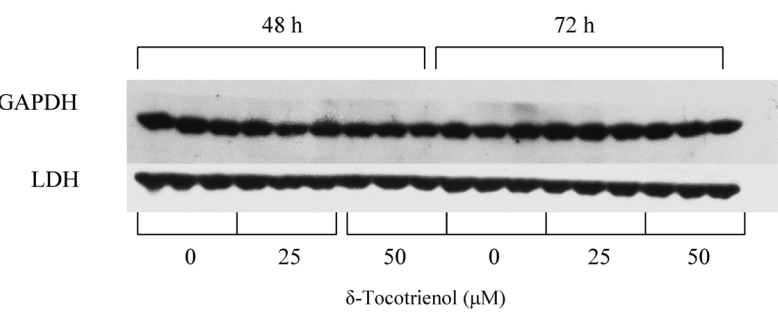

C
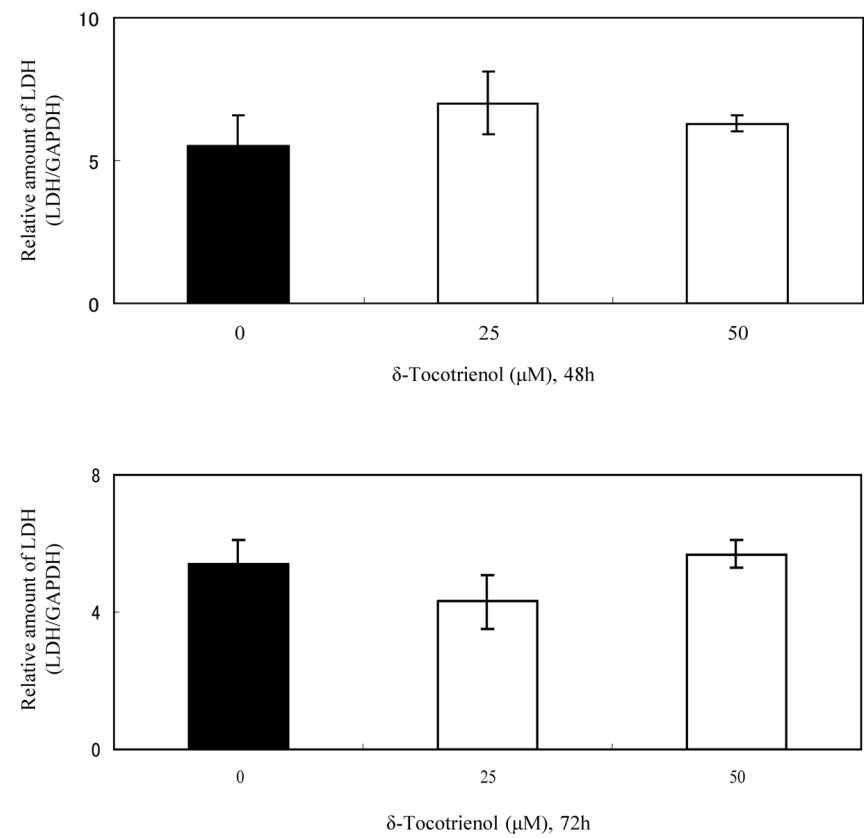
showed cytotoxicity. The amount of protein in cells treated with 25 or $50 \mu \mathrm{M} \delta$-tocotrienol for 48 or $72 \mathrm{~h}$ was similar to that in untreated cells. The amount of LDH quantified using GAPDH as an internal control was also similar to that in control cells (Figs. 1B, C). These results indicated that cells survived treatment with up to $50 \mu \mathrm{M}$ of $\delta$-tocotrienol for $72 \mathrm{~h}$.

The Effect of $\delta$-Tocotrienol on Melanin Levels in Cells We examined the dose-dependent effect of $\delta$-tocotrienol long term on melanin levels in cells. The cells were exposed to $\delta$ tocotrienol at various concentrations ranging from 25 or $50 \mu \mathrm{M}$ for 48 or $72 \mathrm{~h}$. The cells showed hypo-pigmentation dependent on dose (Fig. 2A). The melanin content decreased by $44 \%$ or $50 \%$ for $48 \mathrm{~h}, 14 \%$ or $21 \%$ for $72 \mathrm{~h}$ by treatment with 25 or $50 \mu \mathrm{M} \delta$-tocotrienol, respectively, compared to control cells (Fig. 2B). The melanin content significantly decreased by treatment with 25 or $50 \mu \mathrm{M} \delta$-tocotrienol for $48 \mathrm{~h}$ and $50 \mu \mathrm{M} \delta$-tocotrienol for $72 \mathrm{~h}$. Therefore, melanin content was significantly affected by the concentration of $\delta$-tocotrienol $(p<0.0001)$, but not by the length of treatment $(p<0.5)$ (Fig. 2).

The Effect of $\delta$-Tocotrienol on Tyrosinase Activity in Cells We examined the dose-dependent effect of $\delta$-tocotrienol long term on tyrosinase activity in cells. Tyrosinase activity decreased by $50 \%$ and $75 \%$ at $48 \mathrm{~h}$, and by $25 \%$ and $50 \%$ after $72 \mathrm{~h}$, in cells treated with 25 and $50 \mu \mathrm{M} \delta$-tocotrienol, respectively, compared to control levels (Fig. 3). Tyrosinase activity significantly decreased on treatment with 25 or $50 \mu \mathrm{M} \delta$-tocotrienol for $48 \mathrm{~h}$ and $72 \mathrm{~h}$. Therefore, tyrosinase activity was significantly affected by the concentration of $\delta$-tocotrienol $(p<0.0000000001)$ and period of treat-

A
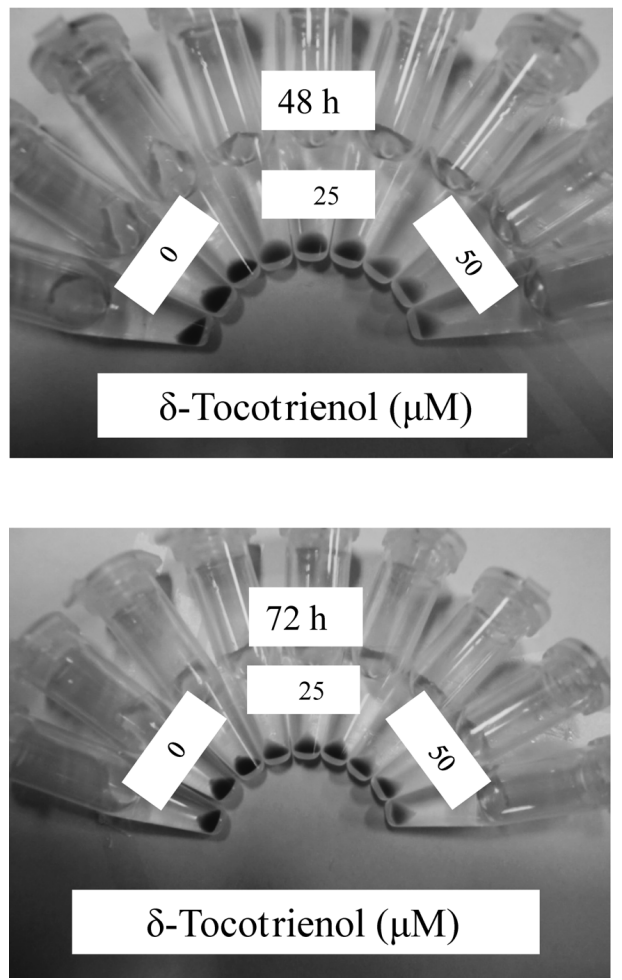

ment $(p<0.000001)$ (Fig. 3)

The Effect of $\delta$-Tocotrienol on Tyrosinase Levels in Cells We examined the dose-dependent effect of $\delta$-tocotrienol long term on the amount of tyrosinase in cells. The amount decreased by $20 \%$ and $45 \%$ at $48 \mathrm{~h}$, and by $75 \%$ and $80 \%$ at $72 \mathrm{~h}$ in cells treated with 25 and $50 \mu \mathrm{M} \delta$-tocotrienol, respectively, compared to that in control cells (Fig. 4). The amount of tyrosinase significantly decreased on treatment with $50 \mu \mathrm{M} \delta$-tocotrienol for $48 \mathrm{~h}$ and 25 or $50 \mu \mathrm{M} \delta$-tocotrienol for $72 \mathrm{~h}$. The decrease was dependent on the dose of $\delta$-tocotrienol. Namely, the amount of tirosinase was affected by the concentration of $\delta$-tocotrienol $(p<0.000005)$ and the length of the treatment $(p<0.005)$ (Fig. 4).

The Effect of $\delta$-Tocotrienol on TRP-1 and TRP-2 Levels in Cells We measured the amounts of enzymes producing melanin using immunoblotting, to examine whether the decrease in melanin content was caused by a specific effect on tyrosinase, or TRP-1 and TRP-2 are also involved. The amount of TRP- 1 decreased by $42 \%$ and $82 \%$ at $48 \mathrm{~h}$, and by $78 \%$ and $77 \%$ at $72 \mathrm{~h}$ in cells treated with 25 and $50 \mu \mathrm{M} \delta$-tocotrienol, respectively (Figs. 5A,B). Treatment with $50 \mu \mathrm{M}$ $\delta$-tocotrienol for $48 \mathrm{~h}$ significantly decreased the amount of TRP-1 (Figs. 5A, B). Although treatment with $\delta$-tocotrienol for $72 \mathrm{~h}$ markedly decreased the amount of TRP-1, the change was not significant. Therefore, the amount of TRP-1 was significantly affected by the concentration of $\delta$-tocotrienol $(p<0.0005)$, but not by the length of treatment $(p<0.068)$ (Figs. 5A, B).

At $48 \mathrm{~h}$, the amount of TRP-2 increased by $20 \%$ at $25 \mu \mathrm{M}$ $\delta$-tocotrienol, but significantly decreased by $52 \%$ at $50 \mu \mathrm{M}$

\section{B}
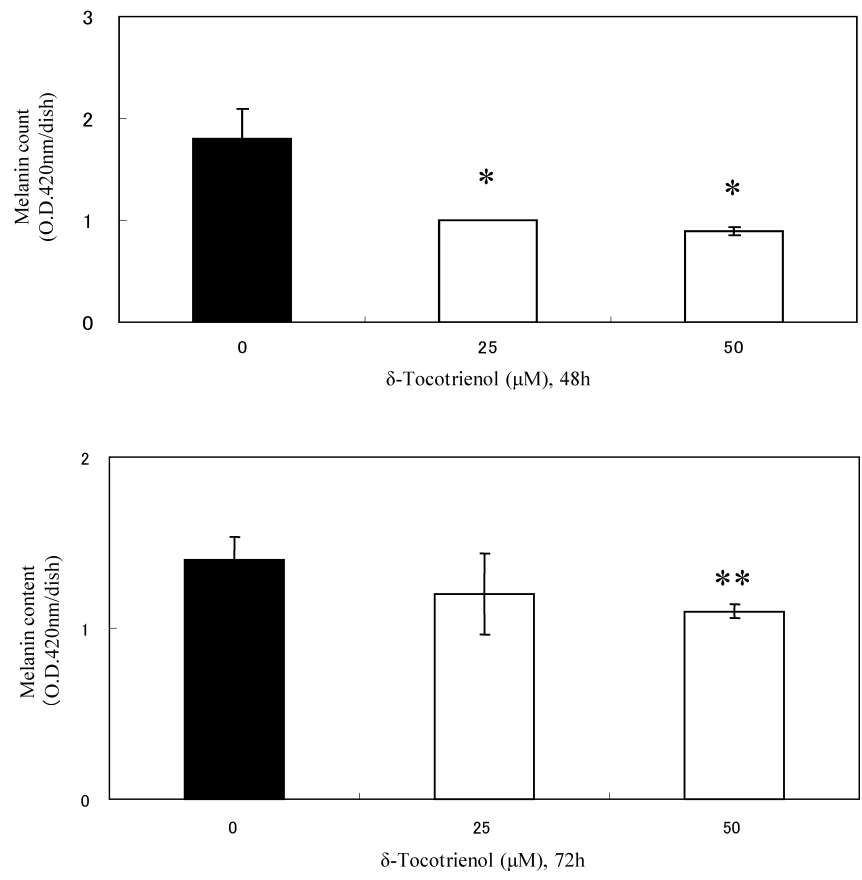

Fig. 2. Inhibition of Cellular Pigmentation and Reduction of Melanin Content by $\delta$-Tocotrienol

(A) B16 melanoma cells were treated with 25 or $50 \mu \mathrm{M} \delta$-tocotrienol for 48 or $72 \mathrm{~h}$, and then collected by centrifugation. (B) Melanin content was measured as described in Materials and Methods. Data are the means for three identical experiments. Significant differences: $* p<0.01, * * p<0.05$. 

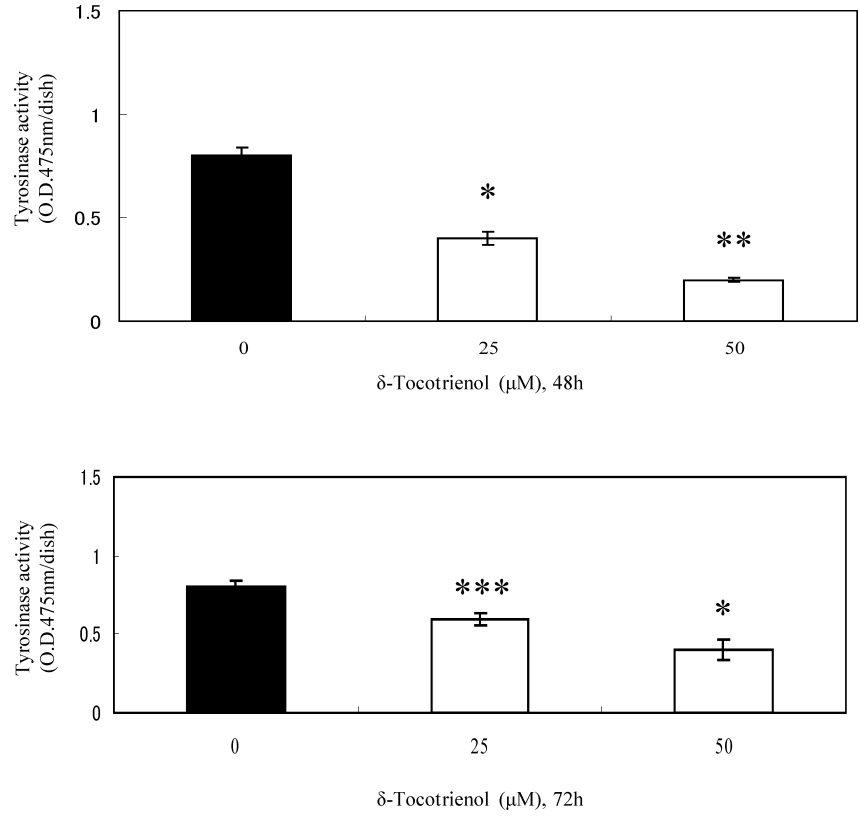

Fig. 3. Tyrosinase Activity in Cells Treated with $\delta$-Tocotrienol

Tyrosinase activity in PNS was measured as described in Materials and Methods. Data are the means for three identical experiments. Significant differences: $* p<0.001$, $* * p<0.00001, * * * p<0.005$

A

Tyrosinase

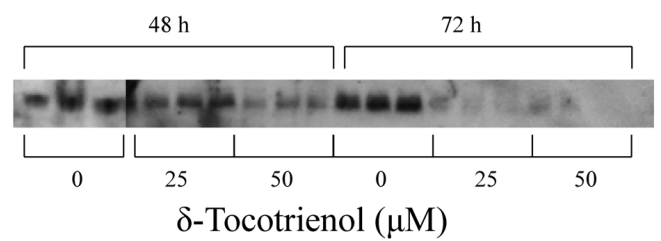

B
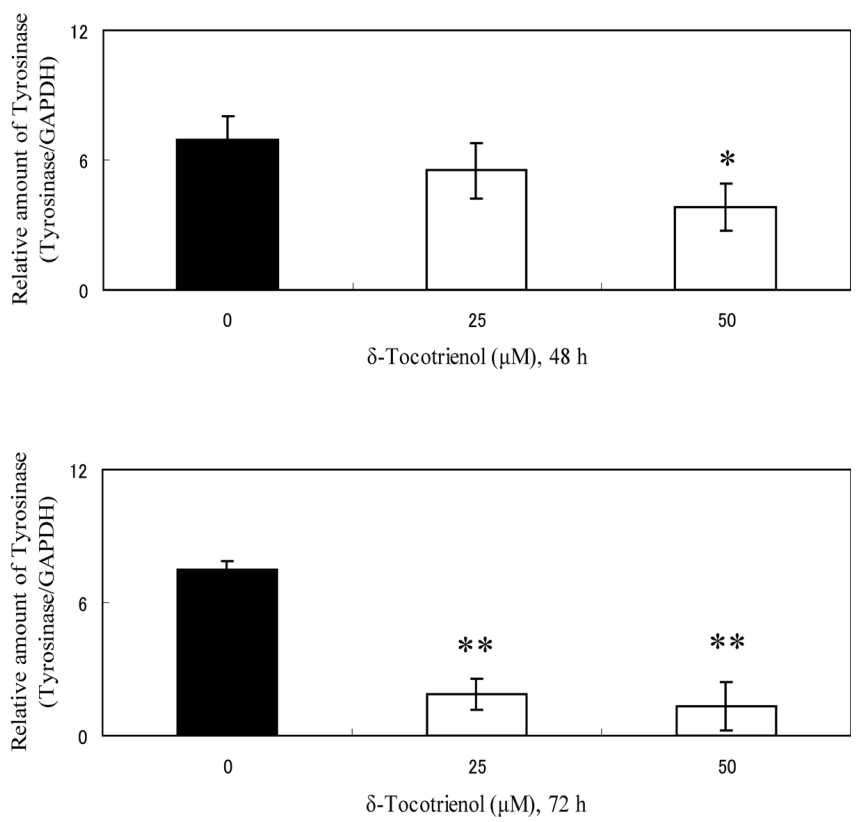

Fig. 4. Amount of Tyrosinase in Cells Treated with $\delta$-Tocotrienol

(A) PNS $(15 \mu \mathrm{l})$ was subjected to immunoblotting using anti-tyrosinase and antiGAPDH antiserum. (B) The signals in A were measured using an Intelligent Quantifier. GAPDH was used as an internal control. Data are the means for three identical experiments. Significant differences: $* p<0.05, * * p<0.01$.
(Figs. 5C, D). At $72 \mathrm{~h}$, the amount of TRP-2 significantly decreased by $55 \%$ and $75 \%$ on treatment with 25 and $50 \mu \mathrm{M} \delta$ tocotrienol, respectively. Therefore, the amount of TRP-2 was significantly affected by the concentration of $\delta$-tocotrienol $(p<0.05)$ as well as the period of treatment $(p<0.01)$ (Figs. 5C, D).

\section{DISCUSSION}

We previously reported that melanin content, and tyrosinase protein levels were significantly reduced in cells treated with $50 \mu \mathrm{M} \delta$-tocotrienol for $24 \mathrm{~h}$, but not tyrosinase mRNA levels, and that melanin content, and tyrosinase protein and mRNA levels were significantly reduced in cells treated with $100 \mu \mathrm{M} \delta$-tocotrienol for $24 \mathrm{~h}$, indicating both $50 \mu \mathrm{M}$ and $100 \mu \mathrm{M} \delta$-tocotrienol to be no cytotoxic. ${ }^{13)}$ In the present study, the amount of protein in cells treated with $50 \mu \mathrm{M} \delta$-tocotrienol for 48 or $72 \mathrm{~h}$ was similar to that in control cells, however, the amount in cells treated with $100 \mu \mathrm{M} \delta$-tocotrienol for $48 \mathrm{~h}$ decreased by $60 \%$, as compared with control values. It was reported that a tocotrienol-rich fraction from palm oil, but not alpha-tocopherol, reduced the viability of activated pancreatic stellate cells by setting up a full death program, independent of cell cycle regulation, and activated pancreatic stellate cells died both through apoptosis, as indicated by increased DNA fragmentation and caspase activation, and through autophagy, as denoted by the formation of autophagic vacuoles and LC3-II accumulation. ${ }^{21)}$ From these results, it was suggested that the cytotoxicity in cells treated with $100 \mu_{\mathrm{M}} \delta$-tocotrienol was caused by apoptosis (decrease in mRNA level) and autophagy (increase in degradation of protein) from $24 \mathrm{~h}$ onward. Therefore, $50 \mu \mathrm{M}$ may be the optimum concentration of $\delta$-tocotrienol for reducing melanin content.

Kamei et al. reported that $\delta$-tocopherol has cytotoxicity, although it showed antimelanogenic activity at a low concentration long term $(72 \mathrm{~h}){ }^{15)}$ It was thought that $\delta$-tocotrienol permeated the cells, as the side chain of $\delta$-tocotrienol and $\delta$ tocopherol is a farnesyl group (containing a double bond) and a saturated phytyl group (not containing a double bond), respectively. However, cells treated with $50 \mu \mathrm{m} \delta$-tocotrienol for 48 or $72 \mathrm{~h}$ showed no cytotoxicity in the present study. The difference in cytotoxicity of between $\delta$-tocopherol and $\delta$-tocotrienol might be due to the experimental conditions. We replaced D-MEM (1 $\mathrm{ml} ; 35-\mathrm{mm}$ dish) with or without $\delta$ tocotrienol at intervals of $24 \mathrm{~h}$. Kamei et al. cultured (48-well plates) their cells in the presence of $\delta$-tocopherol for $3 \mathrm{~d}$.

In the present study, the maximal decrease $(50 \%)$ in melanin content caused by the decrease in enzymes of melanin biosynthesis was obtained after $48 \mathrm{~h}$ of treatment with $50 \mu \mathrm{M} \delta$-tocotrienol (Fig. 2). The amount of TRP-1 and TRP-2 as well as tyrosinase was also significantly decreased by $50 \mu \mathrm{M} \delta$-tocotrienol after 48 h (Figs. $4-6$ ). Therefore, the decrease in the melanin content of cells treated with $50 \mu \mathrm{M}$ $\delta$-tocotrienol for $48 \mathrm{~h}$ was caused by a reduction in the amount of TRP-1 and TRP-2 as well as tyrosinase. We previously reported that tyrosinase degradation is more important than the decrease of mRNA, as cells treated with $50 \mu \mathrm{M} \delta$-tocotrienol for $24 \mathrm{~h}$ was caused the reduction of protein level of tyrosinase, but not mRNA level. ${ }^{13)}$ From these findings, it was suggested that the degradation of melanosome may be 
A

TRP-1

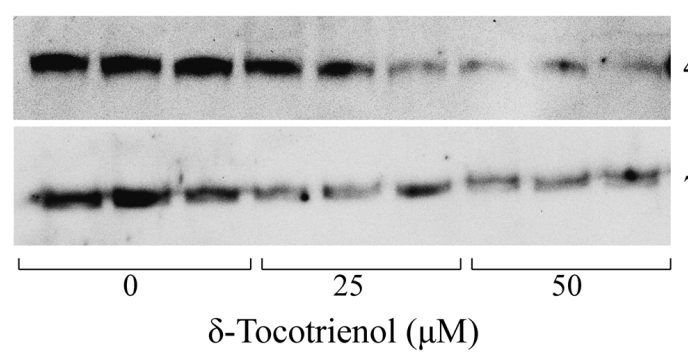

B
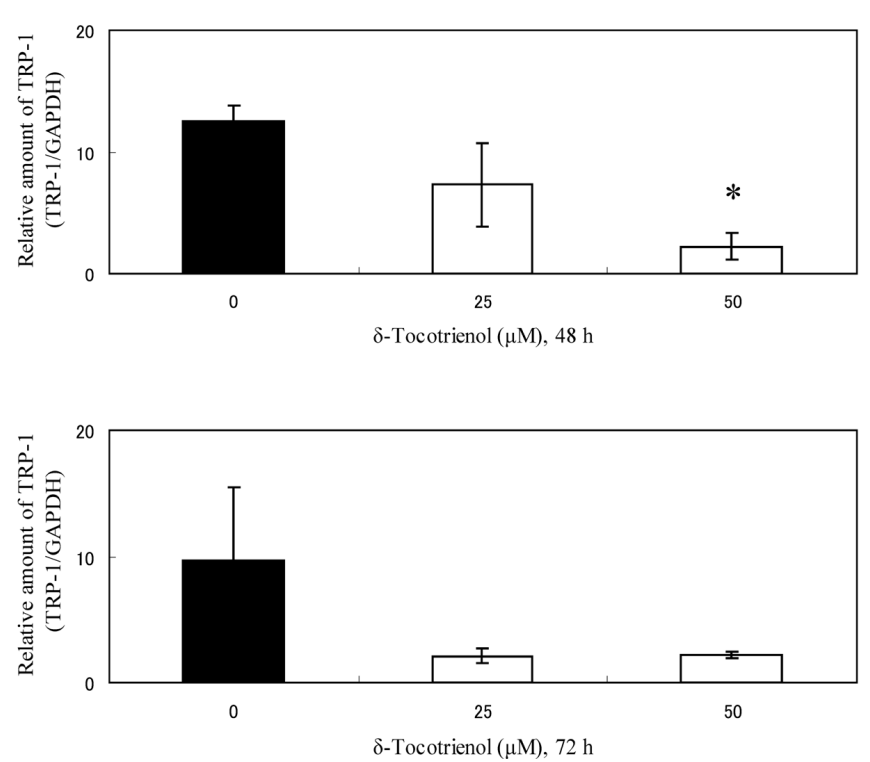

C

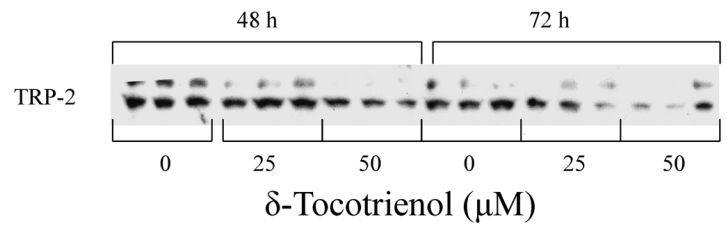

D
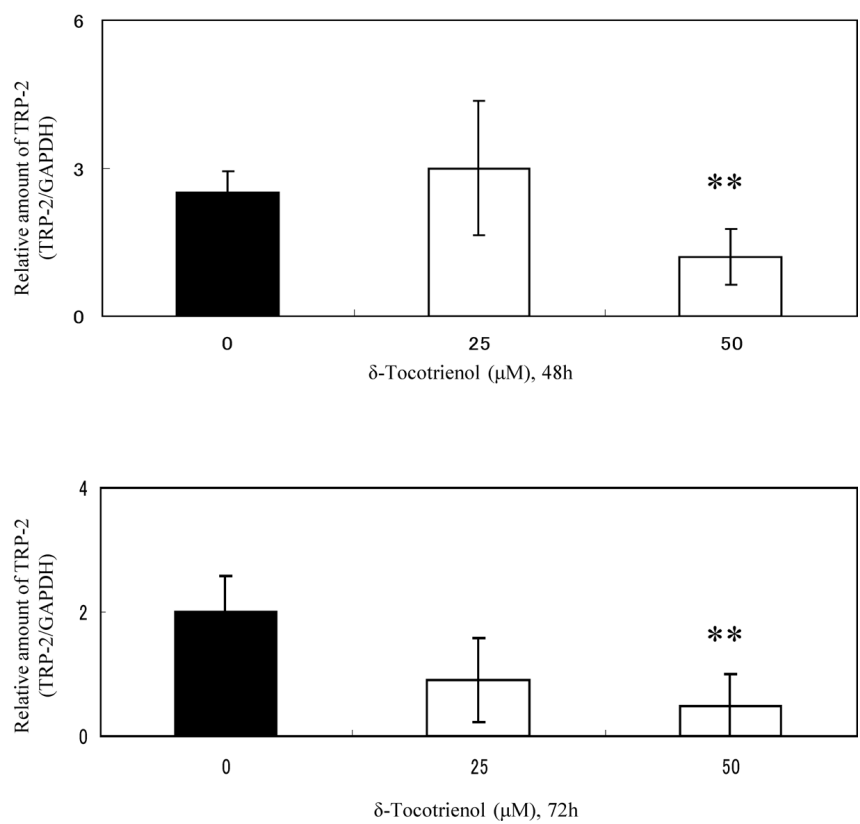

Fig. 5. Amounts of TRP-1 and TRP-2 in Cells Treated with $\delta$-Tocotrienol

(A) PNS (15 $\mu$ l) was subjected to immunoblotting using anti-TRP-1, and anti-GAPDH antiserum (Fig. 1B). (B) The signals in A were measured using an Intelligent Quantifier. (C) PNS $(15 \mu \mathrm{l}$ ) was subjected to immunoblotting using anti-TRP-2 and anti-GAPDH antiserum (Fig. 1B). (D) The signals in C were measured using an Intelligent Quantifier. GAPDH was used as an internal control (Fig. 1B). Data are the means for three identical experiments. Significant differences: $* p<0.001, * * p<0.05$.

caused by the bulk degradation of transient autophagy induced by $\delta$-tocotrienol. The results may be caused by the decrease in melanin synthesis-related enzymes.

Treatment with $\delta$-tocotrienol induced dose-dependent decreases in melanin content, tyrosinase activity, and amounts of tyrosinase, TRP-1 and TRP-2 (Figs. 2-5). However, the effect of the length of treatment on melanin content $(p<0.5)$ and the amount of TRP1 $(p<0.068)$ was not significant, although that on tyrosinase activity, and the amounts of tyrosinase and TRP-2 was (Figs. 2, 5). From these results, it was suggested that the inhibitory effect of $\delta$-tocotrienol on melanin content may be decreased from $72 \mathrm{~h}$, although the reason for the increase for $72 \mathrm{~h}$ remains unclear. It was reported that the level of cyclin D1 in cells treated with $\delta$-tocotrienol decreased for $24 \mathrm{~h}$, however, it was increased at $72 \mathrm{~h}$ as compared with $24 \mathrm{~h}^{22)}$ It was also reported that two forms of tyrosinase existed in B16 mouse melanoma cells. ${ }^{23)}$ One form was present in the microsomal fraction though not in melanosomes. ${ }^{23)}$ In the present study, the amount of tyrosinase decreased with time, although a decreased rate of tyrosinase activity and melanin content increased with time. From these findings, it was suggested that the increase in melanin content at $72 \mathrm{~h}$ was due to an increase in an isozyme of tyrosinase (not reacting with our antibody) and other enzymes involved in melanin biosynthesis or by the production of novel melanosomes from the microsomes. Further studies are necessary to understand these mechanisms.

In conclusion, $\delta$-tocotrienol at up to $50 \mu \mathrm{M}$ dose-dependently caused a reduction in melanin content by reducing levels of TRP-1 and TRP-2 as well as tyrosinase, and showed no cytotoxicity.

Acknowledgement This study was supported in part by grants from the Eizai Food Chemical Co. Ltd. of Japan.

\section{REFERENCES}

1) Sen C. K., Khanna S., Roy S., Life Sci., 78, 2008-2098 (2006).

2) Qureshi A. A., Pearce B. C., Nor R. M., Gapor A., Peterson D. M., Elson C. E., J. Nutr., 126, 389-394 (1996).

3) Qureshi A. A., Bradlow B. A., Brace L., Manganello J., Peterson D. M., Pearce B. C., Wright J. J., Gapor A., Elson C. E., Lipids, 30, 1171-1177 (1995).

4) Qureshi A. A., Qureshi N., Hasler Rapacz J. O., Weber F. E., Chaudhary V., Crenshaw T. D., Gapor A., Ong A. S., Chong Y. H., Peterson D., Rapacz J., Am. J. Clin. Nutr., 53, 1042S-1046S (1991).

5) Qureshi A. A., Qureshi N., Wright J. J., Shen Z., Kramer G., Gapor A., Chong Y. H., Dewitt G., Ong A., Peterson D. M., Bradlow B. A., Am. J. Clin. Nutr., 53, 1021S-1026S (1991).

6) Qureshi A. A., Burger W. C., Peterson D. M., Elson C. E., J. Biol. Chem., 261, 10544-10550 (1986).

7) Theriault A., Chao J. T., Wang Q., Gapor A., Adeli K., Clin. Biochem., 
32, 309-319 (1999).

8) Nesaretnam K., Stephen R., Dils, Darbre P., Lipids, 33, 461-469 (1998).

9) Pearce B. C., Parker R. A., Deason M. E., Qureshi A. A., Wright J. J., J. Med. Chem., 35, 3595-3606 (1992).

10) Pearce B. C., Parker R. A., Deason M. E., Dischino D. D., Gillespie E., Qureshi A. A., Volk K., Wright J. J., J. Med. Chem., 37, 526-541 (1994).

11) Song B. L., DeBose-Boyd R. A., J. Biol. Chem., 281, 25054-25061 (2006).

12) Shibata A., Nakagawa K., Sookwomg P., Tsuduki T., Tomita S., Shirakawa H., Komai M., Mizoyama T., J. Nutr., 138, 2136-2142 (2008).

13) Michihara A., Morita S., Hirokawa Y., Ago S., Akasaki K., Tsuji H., J. Health Sci., 55, 314-318 (2009).

14) Michihara A., Shimatani M., Akasaki K., J. Health Sci., 56, 355-360 (2010).
15) Kamei Y., Otsuka Y., Abe K., J. Nutr., 59, 183-190 (2009).

16) Lowry O. H., Rosebrough N. J., Farr A. L., Randall R. J., J. Biol. Chem., 193, 265-275 (1951).

17) Lee T. H., Lee M. S., Lu M. Y., Endocrinology, 91, 1180-1188 (1998).

18) Hirosaki K., Yamashita T., Wada I., Jin H. Y., Jimbow K., J. Invest. Dermatol., 119, 475-80 (2002).

19) Laemmil U. K., Nature (London), 227, 680 - 685 (1970).

20) Towbin H., Staehelin T., Gordon J., Proc. Natl. Acad. Sci. U.S.A., 76, 4350- 4354 (1979).

21) Rickmann M., Vaquero E. C., Malagelada J. R., Molero X., Gastroenterology, 132, 2518-2532 (2007).

22) Elangovan S., Hsieh T. C., Wu J. M., Anticancer Res., 28, 2641-2647 (2008).

23) Jimenez-Cervantes C., Garcia-Borron J. C., Valverde P., Solano F., Lozano J. A., Eur. J. Biochem., 217, 549-556 (1993). 